DOI 10.31558/2519-2949.2020.1.6

УДК 342.722 .1

ORCID ID: https://orcid.org/0000-0003-4186-4246

Неприцька Т. І., Донецький національний університет імені Василя Стуса

ORCID ID: https://orcid.org/0000-0001-9536-2538

Неприцький О. А., Вінницький державний педагогічний університет імені Михайла Коцюбинського

\title{
РОЗШИРЕННЯ МОЖЛИВОСТЕЙ ДОСЯГНЕННЯ ГЕНДЕРНОГО ПАРИТЕТУ В ПОЛІТИЦІ В КОНТЕКСТІ ДЕЦЕНТРАЛІЗАЦІЇ ВЛАДИ В УКРАЇНІ
}

Прочес децентралізачії є багатогранним та складним. Передача владних повноважень вимагає від громад вищого рівня продуктивності та результативності їх діяльності. Разом із запровадженням децентралізації, зростає роль органів місиевого самоврядування, адже саме вони стають первинною та чи не найголовнішою ланкою, котра відповідає за добробут та спроможність своєї громади. Проекти та програми міжнародної технічної допомоги відіграють важливу роль у впровадженні реформи, надаючи консультачійну, експертну, організаційну та фінансову допомогу. Окрім того, вони приділяють особливу увагу гендерному питанню, вважаючи, що дане питання є одним із визначальних для забезпечення сталого розвитку держави. Метою даної статті є проаналізувати яким чином процеси децентралізації вплинули на динаміку розвитку гендерного питання, особливо в контексті можливостей для політичної участі жінок в житті суспільства загалом та їх громади зокрема. Закон про місиеві вибори 2015 року був першим законом України, де визначалася «гендерна квота», а саме не менше 30 відсотків представників однієї статі у партійному списку. Проте не ставилися вимоги щодо місия у списку та не передбачалося санкиій за недотримання даної квоти. Виборчий кодекс, щчо набрав чинності в Украӥні з 1 січня 2020 року, теж передбачає гендерну квоту у 30 відсотків, окрім того, для списків кандидатів у багатомандатних виборчих округах для адміністративно-територіальних одиниць з числом вибориів понад 90 000, законодавець передбачив не менше 2 представників однієї статі у кожній n’ятіриі списку. На відміну від Закону 2015 року в новому Виборчому кодексі гендерні вимоги включено до порядку висування кандидатів. А порушення порядку висування тягне за собою відмову у реєстрачії. Таким чином, вперше з'явилася можливість застосування санкиій за порушення гендерного паритету у виборчих списках партій. Прочеси децентралізаиії значно розиирили повноваження та можсливості органів місцевого самоврядування. Це, в свою чергу, стимулювало включення більшої кількості жінок в політичні прочеси та процеси прийняття рішень в громаді. Прочеси децентралізації позитивно впливають на залученість громад загалом та активних жінок зокрема до процесу прийняття рішень, стимулюють просування гендерної рівності «знизу» тим самим формуючи відповідне соціокультурне бачення та џџннісні орієнтації в суспільстві.

Ключові слова: дечентралізачія, гендерна рівність, виборчий кодекс, гендерна квота, гендерні стереотипи.

Процес децентралізації завжди довготривалий та складний, адже в ньому потрібно врахувати інтереси багатьох сторін, знайти компроміс по багатьох питаннях і при цьому не втратити «життєздатність» системи. Процес децентралізації та передачі влади і повноважень на місця торкається чи не кожної сфери функціонування суспільства. Це і передача владних повноважень, і розширення прав і можливостей для місцевого самоврядування, і посилення міжрегіональної співпраці, і фіскальна децентралізація, і впровадження супутніх секторальних реформ тощо. Очевидно, що такі грунтовні зміни докорінним чином впливають на суспільство в цілому, та на окремі соціальні групи зокрема.

Ще одним питанням, котре викликає значний інтерес суспільства, породжує вир дискусій та немає однозначної відповіді та бачення в суспільстві - це питання гендеру у найширшому його розумінні. На жаль, наразі немає єдиної, чітко сформованої гендерної політики, існують сильні 
відмінності в стереотипному баченні «чоловічих» та «жіночих» ролей у представників сільських та міських громад, а також у сприйнятті таких нововведень як гендерно-орієнтоване бюджетування громад, гендерна квота у списках політичних партій на виборах тощо.

Метою даної статті $є$ проаналізувати яким чином процеси децентралізації вплинули на динаміку розвитку гендерного питання, особливо в контексті можливостей для політичної участі жінок в житті суспільства загалом та їх громади зокрема.

Питання децентралізації досліджувало багато зарубіжних, а також вітчизняних науковців. Серед українських вчених варто виділити таких як Т. Безверхнюк, Ю. Ганущака, О. Голинської, С. Давтяна, В. Куйбіди, Ю. Молодожен, О. Ольшанського, Л. Приходченко, С. Саханєнка, А. Ткачука та ін.

Проте власне гендерний аспект децентралізації, хоч і став предметом уваги власне політиків та політичного процесу в цілому, залишився відносно позі увагою науковців.

Починаючи з 2014 року в Україні розпочався процес децентралізації влади та передачі повноважень та фінансових інструментів забезпечення діяльності на місця. Даний процес відповідає вимогам Свропейської хартії місцевого самоврядування [1], котра була підписана Україною та набула чинності 1 січня 1998 року, що по суті означало, що Україна взяла на себе зобов'язання привести місцеве самоврядування в державі у відповідність до положень даної Хартії. Та лише починаючи з 2014 року почалося масштабне впровадження реформи по всій території України.

До процесу реалізації реформи з децентралізації долучилася велика кількість програм та проектів міжнародної технічної допомоги (наприклад, ПРОOH, DESPRO, DOBRE, U-LEAD з Свропою, SKL тощо), котрі надавали i продовжують надавати різні види допомоги: консультаційну, експертну, організаційну, фінансову тощо. Дані програми та проекти - це представники тих країн, котрі вже пройшли даний шлях, котрі мають досвід у впровадженні децентралізованої системи управління та котрі є розвиненими демократіями.

Саме вони надають консультаційну та організаційну підтримку органам державної влади (зокрема, міністерству розвитку громад та територій України, котре $є$ провідним у забезпеченні впровадження реформи), вказують на існуючі недоліки законодавства та надають рекомендації щодо пріоритетних напрямків розвитку та вдосконалення. Це також організації, котрі у своїх державах чи структурах пройшли досить довгий шлях до забезпечення високого рівня гендерної рівності у таких сферах суспільного життя як соціальна, економічна, політична тощо. Саме тому, гендерна компонента присутня у процесі реформування адміністративно-територіального устрою та територіальної влади в Україні. Як казав екс Віце-прем'єр-міністр - Міністр регіонального розвитку, будівництва та ЖКГ України Геннадій Зубко: «Не може бути успішним чоловік, який не розуміє гендерну рівність. Не може бути успішною країна, яка не впроваджує гендерних принципів у всіх сферах життя» [2].

У зв'язку з цим, бачимо спроби закріплення принципів гендерної рівності на законодавчому рівні. Чергові місцеві вибори, котрі відбулися 25 жовтня 2015 року, були першими виборами, що відбулися за існування гендерної квоти у виборчому законодавстві. Відповідно до Статті 4 Розділу 1 Закону України про місцеві вибори (котрий був чинний на момент проведення місцевих виборів 2015 року), «Представництво осіб однієї статі у виборчих списках кандидатів у депутати місцевих рад у багатомандатних виборчих округах має становити не менше 30 відсотків загальної кількості кандидатів у виборчому списку» [3]. Дана норма закону викликала досить активне обговорення стосовно іï доцільності та дієвості. 3 одного боку, кількість не означає якість, тому виникало питання як забезпечити професійність жінок у політиці, а не лише їх формальну присутність. Окрім того, законодавець не передбачив жодних санкцій за недотримання даної норми. Але незважаючи на це, на нашу думку, дана норму мала виняткову вагу, адже вона вперше не законодавчому загальнонаціональному рівні привернула увагу до даного питання. Більше того, вона мала свої наслідки.

Так, за результатами гендерного моніторингу, що здійснювався в рамках діяльності ВГО «Комітет Виборців України» «Гендерний моніторинг та сприяння фактичній гендерній рівності на місцевих виборах 2015 року в Україні» за підтримки Ради Європи, ми бачимо, що «В середньому, рівень представництва жінок в списках до міських рад м. Києва та міст-обласних центрів по всій Україні дорівнює 32,1\%. 317278 зареєстрованих кандидатів, 5545 є жінками [4]. Тобто можемо говорити, що формальні можливості для участі жінок у виборчому процесі, а отже, і у подальшому прийняті управлінських рішень, було створено. Інше питання постає у тому, чому при досить широких можливостях, досить невелика кількість жінок входить до складу представницьких органів 
влади. Так, за результатами гендерного моніторингу місцевих виборів 2015 року, в 22 обласних радах кількість жінок-депутатів склала $15 \%$, а в міських радах - 18,1\%. [5].

Досить характерною по всій території країни $\epsilon$ тенденція, що чим вище статус представницького органу - тобто, де більше можливостей, ресурсів, фінансів та впливу - тим удепутатському корпусі представництво жінки $є$ нижчим. Разом з тим, якщо подивитись на виконавчі комітети місцевих рад - там ситуація з точністю навпаки - працює абсолютна більшість жінок, які кожного дня роблять свою роботу і реалізовують проекти [2]. Саме тому, доцільно говорити не лише про представництво жінок в органах місцевого самоврядування, а ще й звертати увагу на те, який відсоток жінок обіймає керівні посади.

Варто відзначити, що зі зміною керівництва держави не відбулося докорінного зміну вектору державної гендерної політики, а отже продовжуються вживатися заходи для забезпечення рівних можливостей жінок та чоловіків загалом і у політичному полі зокрема. У новому виборчому кодексі, було прийнято 19 грудня 2019 року, та котрий набув чинності 1 січня 2020 року вказані в контексті місцевих виборів нові гендерні квоти. Так, відповідно до Статті 229 п. 9 сказано, що «Під час формування єдиного та регіональних виборчих списків організація партії повинна забезпечити присутність у кожній п'ятірці (місцях з першого по п'яте, з шостого по десяте і так далі) кожного виборчого списку чоловіків і жінок (не менше двох кандидатів кожної статі)», а в Статті 220, де йдеться про порядок висування кандидатів у депутати сільської, селищної, міської (міста з кількістю виборців до 90 тисяч осіб), районної у місті, районної ради організацією партії, у пункті 7 сказано, що «під час формування списку кандидатів до відповідної ради організація партії повинна забезпечити представництво не менше 30 відсотків осіб однієї статі у загальній кількості кандидатів до відповідної ради» [6].

Як бачимо у новому кодексі питання законодавчих можливостей для дотримання гендерної рівності не те що не зазнало ніяких втрат, а, навпаки, дані норми було поширено, а вимоги стали жорсткішими. Особливу увагу привертає саме пункт про формування регіональних виборчих списків для великих населених пунктів та адміністративно-територіальних одиниць. Як нами вже зазначалося, чим вище рівень органу представницької влади, тим менша кількість жінок у ньому представлена. За новим кодексом, можливості жінок для участі у виборчому процесі максимально розширили. Фактично, якщо дотримуватися вимоги про не менше 2 осіб однієї статі в кожній п’ятірці списку, то гендерна квота в такому випадку складатиме не менше 40\%.

Характерною особливістю нового Виборчого кодексу стало розміщення вимог щодо гендерних квот у порядку висування та реєстрації кандидатів на місцевих виборах (Розділ XXXVII). Ця норма набула абсолютно нової ваги з огляду на Ст. 230. «Відмова в реєстрації кандидата (кандидатів) у депутати, кандидатів на посаду сільського, селищного, міського голови, старости села, селища», яка першим пунктом зазначає, що «порушення встановленого цим Кодексом порядку висування кандидатів» $є$ підставою для відмови у реєстрації кандидатів у депутати. Таким чином Кодекс дає право відповідним комісіям відмовляти у реєстрації кандидатів тим політичним партіям, які знехтують вимогу паритетного гендерного представництва у списках кандидатів на місцевих виборах.

Звичайно, ми не можемо передбачити, яка буде запроваджена політична традиція у виборчих комісіях: відмовляти у реєстрації чи ігнорувати дану норму Виборчого кодексу. Проте, найбільш вірогідно, що комісіям доведеться іії застосовувати, оскільки в разі порушення комісіями вимоги гендерного паритету у списках кандидатів політичних партій, будуть звернення інших суб'єктів виборчого процесу (виборців, організацій політичних партій тощо) до суду із вимогою скасувати реєстрацію. І якщо суди приймуть відповідні рішення, то комісії будуть змушені виконувати рішення суду.

Виконання норми про гендерне представництво у списках кандидатів ще не означає, що такі списки у незмінному стані потраплять до виборця у день голосування. Якщо змоделювати ситуацію, що політична партія не може набрати відповідну кількість представників певної статі до всіх виборчих списків кандидатів, то вакансії будуть заповнювати будь-ким, хто не має жодних політичних амбіцій, а просто погодиться, щоб його кандидатуру внесли до виборчого списку. Далі можемо прогнозувати два варіанти розвитку подій. Перший- ці кандидати, що були внесені до списку лише для виконання вимоги гендерного представництва (або партійні організації, які їх висунули), пишуть звернення до відповідної виборчої комісії про відмову від балотування (або партії пишуть звернення про скасування рішення про реєстрацію кандидата), і їх реєстрація скасовується відповідно до ст.231 Виборчого кодексу, а прізвища не потрапляють до виборчого 
бюлетеня. Або другий варіант - вони формально залишаються кандидатами, але не проводять жодної агітаційної роботи та не мають жодного реалістичного шансу бути обраними до ради відповідного рівня.

I перший, i другий варіант має певні ризики щодо ведення передвиборчої кампанії. Якщо кандидати масово напишуть звернення про відмову від балотування, то конкуренти подадуть ситуацію виборцям, як таку, що партія втрачає довіру і «криси втікають 3 корабля». Якщо партія звернеться до виборчих комісій зі зверненням про скасування рішення про реєстрацію одночасно багатьох кандидатів, то конкурентами підніметься питання надійності політичної сили, і дуже важко буде партії, що написала такі звернення, подати це як процес «самоочищення». У випадку, коли всі кандидати, які були введені для виконання законодавчої норми про гендерне представництво, залишаються в списках, ставиться під удар партія як така, що висунула кандидатів з низьким соціальним статусом (люди 3 високим соціальним статусом не дадуть згоду на таке включення до списків). Тому, якщо у рамках чинного законодавства партії і зможуть в окремих випадках вдатися до обходу норми про гендерний паритет у списках кандидатів у депутати місцевих рад, то це не матиме масового характеру.

Отож, можемо зробити висновок, що суто із законодавчої точки зору, питання забезпечення рівних можливостей політичної участі жінок та чоловіків в Україні знаходиться на досить високому рівні і існує тенденція до покращення ситуації в даному напрямку, хоча багато чого ще, на думку, авторів, потрібно було б вдосконалити.

Інша сторона медалі, котру ми плануємо розглянути в даній статті, це та політична культура та загальна гендерна стереотипна ментальність, котра $є$ домінуючою в українському суспільстві. Адже на законодавчому рівні окреслюються виключно можливості. Законодавчо не можна «зобов'язати» населення проголосувати за того чи іншого кандидата, не можна «заставити» довіряти жінці. Саме тому, питання формування цінностей та соціокультурних умов, котрі б забезпечували фактичну гендерну рівність в суспільстві, $є$ вкрай важливими.

Саме в цьому контексті, на думку авторів, децентралізація відіграє позитивну роль у становленні фактичної гендерної рівності. В умовах активного впровадження реформи з децентралізації, докорінно змінюються умови роботи влади, зокрема, органів місцевого самоврядування, на місцях. Місцева влада отримала ряд нових повноважень, а отже виникла потреба виконання даних обов'язків. Саме за умов децентралізації, велика кількість інфраструктурних питань знаходиться в компетентності місцевого самоврядування, виникає потреба забезпечувати управління фінансовими ресурсами. Іншими словами, органи місцевого самоврядування у великій мірі стають відповідальними за добробут та комфорт своїх громад.

В українському суспільстві існують досить усталені стереотипи стосовно жінок в політиці, а також ряд об'єктивних причин, котрі перешкоджають повноцінній участі жінок в політиці. За словами соціолога Тамари Марценюк, це такі фактори та стереотипи як «низький соціальний статус жінок, економічна залежність від чоловіків, нерівноцінний розподіл сімейних обов'язків, відсутність центрів із політичної освіти населення, відсутність підтримки жінок-політиків з боку чоловіків та нерозуміння останніми важливості проблеми представлення жінок у владі, вплив стереотипу «політика - чоловіча справа» [7].

Та при цьому, стереотип «берегині», а також необхідність відповідати даному стереотипу сформували у жінок здатність займатися кропіткою роботою, планувати сімейний бюджет, забезпечувати комфорт та добробут в сім'ї. А в умовах децентралізації, у жінок виникла можливість «екстраполювати» дані знання та вміння на всю громаду. Децентралізація відкрила можливості для активних жінок долучитися до життя громади. В рамках провадження реформи та за стимулювання програм та проектів міжнародної технічної допомоги активізувалася проектна діяльність громад. Громадам потрібно було навчитися залучати кошти, писати проекти, активізувати членів громад, проводити роз'яснювальну роботу щодо важливості інфраструктурних проектів, підвищення туристичної та інвестиційної привабливості тієї чи іншої громади чи території. Саме у цій площині жінки, особливо в сільській місцевості, побачили для себе «вікно можливостей». Активні жінки, котрі користувалися авторитетом та повагою в громаді, взяли на себе це завдання, та, дуже часто, досягали успіху.

Завдяки децентралізації громади отримують ресурси, ті ресурси, котрі раніше розподілялися виключно «згори» та в основному «для своїх». Саме ця реформа дозволяє громадам розвивати ініціативи «знизу», популяризувати ідеях партиципаторної демократії та залучати активних громадян до політичного життя, не потребуючи великого «вхідного» капіталу. Ці фактори 
приваблюють жінок, котрі вбачають у всіх цих новаціях особисте вікно можливостей. Адже, досягнувши успіху у громаді, особистий авторитет та добробут жінки також зростає, що дозволяє їй почуватися більш впевнено та розвиває їі внутрішній потенціал, що, в свою чергу, дозволяє ламати існуючі стереотипи про «політика не жіноча справа», «жінкам то непотрібно», «успішна жінка в політиці - нещасна в особистому житті» тощо. При чому варто зазначити, що долати дані стереотипи потрібно у всіх - і у чоловіків, і у жінок, і у тих, хто обирає, і у тих, хто планує бути обраним.

Отже, можемо зробити висновок, що процеси децентралізації позитивно впливають на залученість громад загалом та активних жінок зокрема до процесу прийняття рішень, стимулюють просування гендерної рівності «знизу» тим самим формуючи відповідне соціокультурне бачення та ціннісні орієнтації в суспільстві. На нашу думку, саме подолання існуючих гендерних стереотипів у поєднанні із законодавчим закріпленням рівних прав i можливостей для жінок і чоловіків стимулюватимуть активізацію участі та представництва жінок в політиці. Адже скільки б квот не було визначено на законодавчому рівні, вони не зможуть бути справді ефективними, якщо, з одного боку, жінку потрібно буде «загнати» у виборчий список, а з іншого, виборці не підтримають жінку кандидата саме через існуючі в суспільстві стереотипи стосовно жінок та політики.

\section{Бібліографічний список:}

1. Свропейська Хартія місцевого самоврядування. URL: http://zakon5.rada.gov.ua/laws/show/994_03.

2. Геннадій Зубко. Збільшення представництва жінок в органах місцевого самоврядування має стати трендом. URL: https://www.kmu.gov.ua/news/zbilshennya-predstavnictva-zhinok-v-organah-miscevogosamovryaduvannya-maye-stati-trendom-gennadij-zubko.

3. Закон України «Про місцеві вибори». URL: https://zakon.rada.gov.ua/laws/show/595-19.

4. Результати гендерного моніторингу в рамках діяльності ВГО «КВУ» «Гендерний моніторинг та сприяння фактичній тендерній рівності на місиевих виборах 2015 року в Україні».

URL: http://www.cvu.org.ua/eng/nodes/view/type:news/slug:2015\%D0\%BF\%D0\%BF\%D0\%BF\%D0\%BF\%D0\%BF

5. Скільки жінок серед нардепів, міністрів, мерів та голів сільрад. // Інформаційний ресурс «Слово і Діло». URL: https://www.slovoidilo.ua/2018/03/08/infografika/polityka/skilky-zhinok-sered-nardepiv-ministriv-meriv-taholiv-silrad.

6. Виборчий кодекс України. URL: https://zakon.rada.gov.ua/laws/show/396-20.

7. Тамара Марценюк. Найпопулярніший стереотип це те, що жінка - «Берегиня» $\mathrm{i}$ «Барбі». URL: https://gurt.org.ua/interviews/31236/

\section{References:}

1. Yevropejs`ka khartiya miscevogo samovryaduvannya. URL: http://zakon5.rada.gov.ua/laws/show/994_03.

2. Gennadij Zubko. Zbil`shennya predstavny`cztva zhinok v organax miscevogo samovryaduvannya maye staty` trendom. URL: https://www.kmu.gov.ua/news/zbilshennya-predstavnictva-zhinok-v-organah-miscevogosamovryaduvannya-maye-stati-trendom-gennadij-zubko.

3. Zakon Ukrayiny` «Pro miscevi vy`bory'». URL: https://zakon.rada.gov.ua/laws/show/595-19.

4. Rezul 'taty` gendernogo monitory`ngu v ramkax diyal’nosti VGO «KVU» «G 'enderny `j monitory ’ng ta spry'yannya fakty 'chnij g 'endernij rivnosti na miscevy'x vy'borax 2015 roku v Ukrayini».

URL: http://www.cvu.org.ua/eng/nodes/view/type:news/slug:2015\%D0\%BF\%D0\%BF\%D0\%BF\%D0\%BF\%D0\%BF

5. Skil ky` zhinok sered nardepiv, ministriv, meriv ta goliv sil`rad. // Informacijny`j resurs «Slovo i Dilo». URL: https://www.slovoidilo.ua/2018/03/08/infografika/polityka/skilky-zhinok-sered-nardepiv-ministriv-merivta-holiv-silrad.

6. Vy`borchy`j kodeks Ukrayiny`. URL: https://zakon.rada.gov.ua/laws/show/396-20.

7. Tamara Marcenyuk. Najpopulyarnishy`j stereoty`p ce te, shho zhinka - «Beregy`nya» $i$ «Barbi». URL: https://gurt.org.ua/interviews/31236/

\section{Neprytska T. I., Neprytskyi O. A. Broadening the Opportunities for Reaching Gender Equality in Politics in the Context of Power Decentralization in Ukraine}

The process of decentralization is multi-sided and difficult. The transfer of authority requires a higher productivity and efficiency levels from the communities. Together with introduction of decentralization, the role of local self-government bodies increases as they become the primary and likely most important body that is responsible for the welfare and capacity levels of their community. Projects and programs of international technical support play an important role in reform implementation as they provide advisory, expert, organizational and financial support. In addition, they pay special attention to the gender issue, as they believe that it is one of the crucial ones for ensuring sustainable development of the state. The purpose of this article is to analyze how the decentralization processes influenced the dynamics of the gender issue 
development, specifically in the context of opportunities for political participation of women in the life of the society in general and their community in particular. The 2015 Law of Ukraine "On Local Elections" was the first Law, which introduced a "gender quota", namely, not less than 30 percent of representatives of one sex in the party list. However, there were no requirements as to the place of these candidates in the list and no sanctions were presupposed for violating the observation of this quota. The Electoral Code that was enacted on January 1, 2020 also presupposes a 30 percent gender quota, in addition, the Code states that the candidate lists in the multi-mandate electoral constituencies in the administrative-territorial units that have over 90,000 voters, should have not less than 2representatives of each sex for every five positions in the list. Unlike the Law of 2015, the new Electoral Code includes gender requirements into the procedure of submitting the candidates. And violation of the procedure leads to refusal of registration. Thus, for the first time there are sanctions for violating gender balance in party lists. This, in turn, stimulated the involvement of a greater number of women in the political and decision-making processes in the community. Decentralization processes have a positive influence on involvement of communities in general and of active women in particular in the decision-making process, stimulate the "bottom-up" promotion of gender equality, thus creating a corresponding sociocultural vision and value orientations in the society.

Key words: decentralization, gender equality, electoral code, gender quota, gender stereotypes. 